\title{
AN ANALYSIS ON THE EFFECT OF VIOLENCE REDUCTION PSYCHOEDUCATION PROGRAM ON COMMUNICATION, CONFLICT RESOLUTION AND EMPATHY SKILL LEVELS OF ADOLESCENT STUDENTS
}

\author{
Yunus Akan ${ }^{\mathrm{i}}$ \\ Muş Alparslan University, \\ Muş, Turkey
}

\begin{abstract}
:
The purpose of this study is to examine the effect of the "Violence Reduction Psychoeducation Program (VRPP) for Students Aged 11-18" on the levels of communication, conflict resolution and empathy skills of secondary school students. This research was designed as a semi-experimental design defined as "Pretest-Post-test Control Group Model". The study group of the research consisted of 120 students studying in the Selçuklar secondary school affiliated to the Mersin Provincial Directorate of National Education in the 2018-2019 academic year. "Communication Skills Evaluation Scale", "Empathy Scale for Children and Adolescents" and "Determination of Conflict Resolution Behavior Scale" were used as data collection tools. The program was applied to the experimental group for 8 consecutive weeks with $160-70$-minute session per week at 11 o'clock on Mondays in the conference hall of the school. Independent sample t-test and ANCOVA were used to analyze the data of this research. As a result of the research, it was found that program increased the students' level of communication, empathy and conflict resolution skills in the experimental group. In line with the results obtained, suggestions such as systematic and planned implementation of the developed program at certain hours as part of the curriculum within the scope of the psychological counseling and guidance services were made.
\end{abstract}

Keywords: violence reduction program, aggression, communication, empathy, conflict resolution

\section{Introduction}

Individuals have basic needs such as expressing themselves to others in the society, being accepted by the others and overcoming the problems they face. Basic life skills such as

i Correspondence: email y.akan@alparslan.edu.tr, y.akan@alparslan.edu.tr 
communication, conflict resolution and empathy have an important role in meeting these needs. Individuals who do not have basic life skills have difficulty in adapting to the society. Therefore, it is important to teach individuals basic life skills at an early age. How and where do individuals learn these skills? Schools are the most suitable places for individuals to acquire these skills at an early age, and the most appropriate period is primary school years. Primary school period forms the basis for all developmental aspects of individuals (Tagay, Baydan and Voltan-Acar, 2010).

Failing to teach students basic life skills at an early age could lead to emotional and behavioral problems. According to Farrington (1991), the main problem in overcoming negative behaviors such as violence and aggression is that students cannot acquire basic life skills such as conflict resolution and communication at an early age. Behaviors involving violence and aggression in schools have been increasing everyday (Kabasakal, 2013). The research of the Turkish Grand National Assembly Research Commission on the schools, which concluded that $55.7 \%$ of the students experienced physical violence, $31.9 \%$ experienced verbal violence, $36.3 \%$ experienced emotional violence, and $15.8 \%$ experienced sexual violence, clearly indicated that students lacked basic life skills. Students do not know how to solve a problem when they encounter one. It is not possible to expect basic life skills to develop spontaneously in students without specific education (Stevahn, Johnson, Johnson and Real, 1996). Students experience difficulty in attaining life skills such as conflict resolution and communication without receiving education. Therefore, it is important to administer intervention programs on base life skills to students in addition to academic education. According to the metaanalytical study of Bacıoglu (2014) about the thesis studies on intervention programs for students in Turkey, preventive and protective intervention programs are quite effective on teaching basic life skills to students as well as reducing aggression and violence. Looking at the meta-analytical studies conducted in the international literature, it was found that intervention programs for students were effective methods of reducing violent behaviors (McCart, Prienter, Davies and Azen, 2006; Wilson and Mark, 2007).

It is important that the intervention programs for students include applications, in which students would attain communication skills, conflict resolution skills and empathy skills. Studies have demonstrated that teaching communication skills (Beşer and Çam, 2009; Küçük, 2012; Yıldırım and Abakay, 2015), conflict resolution skills (Arslan, Hamarta, Arslan and Saygın 2010; Ateş, 2014; Kabasakal, Sağkal, Türnüklü, 2016; Kaşık and Kumcağız 2014; Latipun, Zainah, Nasir and Khairudin, 2012) and empathic skills (Hasta and Güler, 2013; Filiz, 2009; Siyez and Kaya, 2011) to students reduced their levels of violence and aggression and increased their positive behaviors. Why is it important to teach students the communication, conflict resolution and empathy skills?

Communication skills are very important for the regulation of interpersonal relationships in social life (Kılıçarslan, 2011). Experiences that are aimed by all people such as happiness, vital pleasure, individual success, succeeding in love, making new friends all depend on the relationships established with other people (Koç, 2014). Those with improved communication skills develop more satisfying relationships, cope better 
with the problems they face in their lives and become more successful in their professional and educational lives. Conflicts are inevitable when communicating with other individuals. Rather than experiencing these conflicts, it is more important to resolve them in a sound manner. How would conflicts arise?

Conflict arises when the impulses, needs and desires of the individuals contradict each other (Öner, 1999). Individuals who experience conflict take either constructive or destructive behaviors to resolve their conflicts. When conflicts are resolved with constructive methods, this provides psychosocial development by improving critical thinking, problem solving and communication skills in students (Balcl, 2017). When conflicts are resolved with destructive methods, students develop feelings of rage, violence, anger and hostility. In conflict situations, students either avoid conflict or use violence because they have not been taught about the correct ways of conflict resolution and they do not know how to deal with conflicts (Korkut, 2004). A study concluded that 7th and 8th grade students used useless and destructive conflict resolution strategies such as verbal violence, physical violence and complaining to an adult rather than constructive methods of conflict resolution (Türnüklü and Şahin, 2004). In other studies, it was observed that students could experience conflicts in the classroom, during the lesson in the school yard, in the school bus or while playing games in the school environment; and they generally tried to resolve these conflicts through physical or verbal violence (Bemak and Keys, 2000; Ögel, Tarı and Eke, 2006). Previous studies have demonstrated that one of the main causes of violence in schools is the lack of conflict resolution skills in students. In order for students to live a successful and happy life that is harmonious with the society they live in, they need to acquire skills that could solve the problems they experience in a sound manner. Students should understand other individuals accurately and look at the events from their perspectives in order to solve conflicts they experience with others constructively. This is where the empathy skills come into foreground.

Empathy is the ability of people to put themselves in the shoes of others and understand their feelings and thoughts accurately. As students improve their empathy skills, the quality of interpersonal relationships they establish would also improve. In cases where empathy skills are weak, communication conflicts are experienced and interpersonal relations are destroyed (Dökmen, 2008). One of the main causes of aggression observed among students is the lack of empathy (Hasta and Güven, 2013). Studies have revealed that empathy skill has a strong relationship with communication and conflict resolution skills (Schreiter et al., 2013; Tully et al., 2015; Yiğitbaş et al., 2013). These results demonstrate that it is important for students to have conflict resolution and empathy skills in addition to communication skills.

Schools, which strive to cultivate healthy generations in all terms, have a great role in providing students with basic life skills such as communication, conflict resolution and empathy. In recent years, bullying, violence and conflict incidents have increased at schools (Tatlılığlu, 2016). According to the results of a comprehensive study carried out with a total of 26677 students enrolled in 261 schools in different regions of Turkey, it was found that $22 \%$ of the students were exposed to physical violence while $35.5 \%$ of the 
students committed physical violence; $53 \%$ of the students were exposed to verbal violence, while $48.7 \%$ of them committed verbal violence; $36.3 \%$ were exposed to emotional violence while $27.6 \%$ of them committed emotional violence; and, $15.8 \%$ of the students were exposed to sexual violence while $11.7 \%$ committed sexual violence (Özcebe, Ulukol, Mollahaliloğlu, Yardım and Karaman, 2008). Another study conducted on 673 students reported that almost half of the students were exposed to violence and bullying at least once (İraner, 2009).

These incidents of violence that are intensively experienced in schools increase the fears of students, affect their learning skills and willingness to learn negatively and cause disruption of education by affecting their physical, social and psychological well-being (Elbogen and Johnson 2009). Looking at these negative developments, it is observed that preventive and protective activities are required in schools. Guidance and psychological counseling departments of schools have a great importance for these protective and preventive activities. There are tens of thousands of guidance counselors/psychological counselors currently employed at schools. It is very important for this great means of strength to implement preventive and protective programs for students to achieve a sound developing generation. In a study, guidance and counseling departments of schools, which are a great strength for schools, are not sufficiently effective in contributing to the development of students and solving their problems (Erdemir and Kiş, 2017).

In order for the guidance and counseling departments to have more contributions to the sound development of students in schools, intervention programs for students should be developed and implemented (Kabasakal, Sağkal and Türnüklü, 2016; Koç, Terzi and Gül, 2015). It would be more functional to implement them as a part of the curriculum similar to other courses (Akgün and Araz, 2010).

There have been studies conducted on the development and implementation of intervention programs for students. The programs developed for adolescent students and the studies conducted on these programs are as follows: The effect of "Conflict Resolution Education Program" on conflict resolution skill levels of students (Ateş, 2014), The effect of "Peer Mediation Education Program" on conflict resolution skill levels of students (Taştan, 2004), The effect of "Peace Education Program" on conflict resolution skills (Latipun, Nasir, Zainah and Khairudin, 2012), communication skills (Damirchi and Bilge, 2014) and empathy skills (Sağkal, 2011) of students, The effect of "Interpersonal Relations Development Program" on communication skills levels of students (Beşer and Çam, 2009), The effect of "Character Education Program" on conflict resolution levels of students (Çokdolu, 2013), the effect of "Anger Management Education Program" on communication skills levels of students (Öz and Aysan, 2011), The effect of "Creative Drama-Based Conflict Resolution Program" on the conflict resolution skills of students (Gündoğdu, 2009), The effect of the "Anti-Violence Education Program" on conflict resolution levels of students (Uysal and Temel, 2009). Looking at the previous studies, no programs were found about developing communication, conflict resolution, emotion management, anger management and empathy skills as a whole in students; and there 
were no studies examining the effect of such a program on the communication, conflict resolution and empathy levels of the students.

In the light of the explanations made above, there is a need for a program to be implemented to the students by the guidance counselors/psychological counselors for developing the communication, conflict resolution, emotion management, anger management and empathy skills of students not individually but as a whole. In order to meet this need, "Violence Reduction Psychoeducation Program (VRPP)", which was developed by Akan (2018) and proven to be effective on aggression and basic life skills of adults, was revised in accordance with the levels of students, and a program that was based on the cognitive behavioral approach was implemented to 7th and 8th Grade students under the name of "Violence Reduction Psychoeducation Program (VRPP) for Students Aged 11-18".

The purpose of this study is to examine the "Violence Reduction Psychoeducation Program (VRPP) for Students Aged 11-18", which was implemented to students enrolled at 7 th and 8th grades, in terms of its effects on their communication, empathy and conflict resolution skill levels. In the light of this main purpose, the following hypotheses were tested for their accuracy:

1) "VRPP for Students Aged 11-18" affects the "Communication Skill" levels of the students.

2) “VRPP for Students Aged 11-18" affects the "Conflict Resolution Skill” levels of the students.

3) “VRPP for Students Aged 11-18" affects the "Empathy Skill" levels of the students.

\section{Method}

\subsection{Research Design}

This study has a semi-experimental design, which is defined as "Pretest-Posttest Control Group Design". The design of the study is given in Table 1.

Table 1: Research Design

\begin{tabular}{lcccc}
\hline Groups & Neutrality & $\begin{array}{c}\text { Measurement 1 } \\
\text { (Pretest) }\end{array}$ & $\begin{array}{c}\text { Experimental } \\
\text { Implementation }\end{array}$ & $\begin{array}{c}\text { Measurement 2 } \\
\text { (Posttest) }\end{array}$ \\
\hline Experimental & $\mathrm{R}$ & $\mathrm{X}$ & $\mathrm{X}$ & $\mathrm{X}$ \\
\hline Control & $\mathrm{R}$ & $\mathrm{X}$ & & $\mathrm{X}$ \\
\hline
\end{tabular}

According to Table 1, the study was carried out with two groups, which were control and experimental groups identified by with neutral assignment. Both groups were administered the pretest before the implementation and the posttest after the implementation by the researchers. While the "Violence Reduction Psychoeducation Program (VRPP) for Students Aged 11-18" was implemented to the experimental group of the study, no implementations were made to the control group. The independent variable of the study was the "VRPP for Students Aged 11-18" and the dependent 
variables were the communication, conflict resolution and empathy skill levels of the students.

\subsection{Study Group}

The study group of the research consisted of 120 students enrolled in the Selçuklar Secondary School under Mersin Provincial Directorate of National Education within the 2018-2019 academic year. One class from the 7th and 8th levels of the secondary school was selected for each of the experimental and control groups by using the simple random sampling method. Information on the experimental and control groups of the study are given in Table 2.

Table 2: Demographic Information About the Study Group

\begin{tabular}{llcccc}
\hline Variables & & \multicolumn{2}{c}{ Experimental Control } & \multicolumn{2}{c}{ Total } \\
\cline { 2 - 6 } & & $\mathrm{n}$ & $\mathrm{n}$ & $\mathrm{n}$ & $\%$ \\
\hline \multirow{2}{*}{ Gender } & Female & 30 & 29 & 59 & 49.2 \\
\cline { 2 - 6 } & Male & 29 & 32 & 61 & 50.8 \\
\hline \multirow{2}{*}{ Grade Level } & 7th Grade & 34 & 33 & 67 & 55.8 \\
\cline { 2 - 6 } & 8th Grade & 25 & 28 & 53 & 44.2 \\
\hline
\end{tabular}

According to Table 2, 50.8\% ( $\mathrm{n}=61)$ of the study group constituted the control group and $49.2 \%(n=59)$ constituted the experimental group. In the study group, $50.8 \%(n=61)$ were male and $49.2 \%(n=59)$ were female; $55.8 \%(n=67)$ were the adolescents enrolled in the 7 th grade and $44.2 \%(n=53)$ were the adolescents enrolled in the 8th grade. There were 59 (29 female, 30 male) adolescents in the experimental group of the study, and 61 (32 female and 29 male) adolescents in the control group. The average age of the experimental group was calculated as $13.10(\mathrm{Sd}=.90$, age range $=12-15)$ and the average age of the control group was calculated as $13.01(\mathrm{Sd}=.76$, age range $=12-15)$.

\subsection{VRPP}

In this study, "Violence Reduction Psychoeducation Program (VRPP)", which was developed by Akan (2018) and observed to be effective on aggression and basic life skills of adults, was used after being adapted to the levels of adolescents. For the adaption of VRPP to the adolescents, first, a literature review was performed to examine the relevant research and different programs. Then, the outline of the program used in this study was prepared in line with the opinions taken from three field experts. The program developed was implemented to a group of 28 people in a 2-session pretest application and it was decided that the program was suitable for the level of students. The weekly schedule for the VRPP program is presented in Table 3. 
AN ANALYSIS ON THE EFFECT OF VIOLENCE REDUCTION PSYCHOEDUCATION PROGRAM ON COMMUNICATION, CONFLICT RESOLUTION AND EMPATHY SKILL LEVELS OF ADOLESCENT STUDENTS

\begin{tabular}{cl}
\hline \multicolumn{1}{c}{ Table 3: VRPP weekly outlines } \\
\hline Week & Subjects \\
\hline 1 & Introduction, communication skills \\
\hline 2 & Communication skills \\
\hline 3 & Conflict resolution skills \\
\hline 4 & Conflict resolution skills \\
\hline 5 & Emotion management skills \\
\hline 7 & Empathy skills \\
\hline 8 & Anger management skills \\
\hline
\end{tabular}

As an example to the sessions, the first session was implemented as follows: Group members were informed about the objectives of the first session. Group members were informed about the communication through the distributed "Communication Elements" form. Then, the items in the "Interpersonal Communication" form distributed to the group members were explained and the members were asked to mark the items which were suitable for them. A volunteer member shared the items s/he marked with the group. The group leader and a volunteer group member talked to each other, first by standing back to back and then by facing each other through eye communication. The group members were paired with their peers, and they were also asked to talk first by standing back to back and then by facing each other. Next, the students were asked the difference between the two types of communication, and the group leader emphasized the importance of non-verbal communication after receiving the answers. The group leader read "A Simple Salute", a story about the importance of communication, to the group members and opinions of several group members were taken about the story. At the end of the session, the group session was summarized and the session was concluded by assigning a homework, which required students to speak to the people they meet using the interpersonal communication elements for a week.

\subsection{Data Collection Tools}

\section{A. Communication Skills Evaluation Scale}

It is a 25-item, one-dimensional and five-point Likert-type scale that was developed by Korkut (1996) to evaluate the communication skills of the adolescents. The internal consistency coefficient of the scale was found to be .80; and the reliability coefficient according to the test-retest method was found to be .76. The high scores that could be obtained on the scale would indicate that the communication skill levels of the students were high. The lowest score to be obtained from the scale is 25 and the highest is 125 .

\section{B. Empathy Scale for Children and Adolescents}

The "Empathy Scale for Children and Adolescents", which was developed by Bryant (1982) and adapted to Turkish by Yüksel (2004), is a scale consisting of 20 items with a dual response form (yes-no), which can be applied to children and adolescents aged 8-14 years. The internal consistency coefficient of the scale was found to be .70 and its testretest reliability coefficient was found to be .76. The high scores that could be obtained 
on the scale would indicate that the empathy skill levels of the students were high. The lowest score to be obtained from the scale is 20 and the highest is 40 .

\section{Conflict Resolution Behavior Determination Scale}

"Conflict Resolution Behavior Determination Scale", which was developed by Koruklu (1998) to measure the responses of middle school students to conflicts, is a 24-point, twodimensional and five-point Likert-type scale. The internal consistency coefficient of the scale was found to be .85 and .83 for the sub-dimensions; and, the test-retest reliability coefficient was found to be .64 and .66 for the sub-dimensions. The high scores that could be obtained on the scale would indicate that the conflict resolution levels of the students were high. The lowest score that can be obtained from the scale is 24 and the highest score is 120 .

\subsection{Process}

The program was carried out with 120 students enrolled in a secondary school affiliated to the Mersin Provincial Directorate of National Education within the 2018-2019 academic year after obtaining the necessary permissions. Before the program was implemented, all groups were informed about the purpose and importance of the study, and they were administered the pretest. After the experimental and control groups were decided, preliminary interviews were made with 59 students in the experimental group and the students were provided with descriptive information such as the purpose of the program, the place of implementation, the time and duration. The program was implemented between September 24, 2018 and November 12, 2018. The program was implemented to the experimental group at 11 o'clock on Mondays in the conference hall of the school for 8 consecutive weeks as 1 session per week and 60-70-minutes per session. No implementations were made to the control group. Finally, the posttest was administered to all groups as soon as the implementation was over.

\subsection{Analysis of the Data}

Assumptions of normality were checked in order to determine the statistical tests to be used in the analysis of the data. The evaluation was made through the skewness (-.500 and .191) and kurtosis (-.836 and .647) values along with the Kolmogrov-Simirnov test results. As a result of this examination, it was observed that the data of the study showed normal distribution. Independent sample t-test and ANCOVA (Covariance Analysis) were used in order to analyze the data of this study. The analysis of the data was carried out using the SPSS Statistics 22.0 package program.

\section{Findings}

Pretest and posttest scores of the experimental and control groups of this research were calculated. Pretest and posttest scores of the experimental and control groups are presented in Table 4. 
AN ANALYSIS ON THE EFFECT OF VIOLENCE REDUCTION PSYCHOEDUCATION PROGRAM ON COMMUNICATION, CONFLICT RESOLUTION AND EMPATHY SKILL LEVELS OF ADOLESCENT STUDENTS

\begin{tabular}{|c|c|c|c|c|c|c|c|}
\hline \multirow[b]{3}{*}{ Scale } & \multicolumn{7}{|c|}{ Table 4: T-test results of experimental and control groups } \\
\hline & \multirow[b]{2}{*}{ Group } & \multirow[b]{2}{*}{$\mathbf{n}$} & \multicolumn{2}{|c|}{ Pre-test } & \multicolumn{2}{|c|}{ Post-test } & \multirow{2}{*}{$\begin{array}{c}\text { Mean } \\
\text { Difference } \\
\text { (Pre-post) }\end{array}$} \\
\hline & & & $x$ & sd & $x$ & sd & \\
\hline \multirow{2}{*}{$\begin{array}{l}\text { Communications } \\
\text { skills }\end{array}$} & Experimental & 59 & 95.30 & 10.40 & 97.64 & 12.76 & +2.34 \\
\hline & Control & 61 & 92.67 & 13.54 & 91.26 & 13.63 & -1.41 \\
\hline \multirow{2}{*}{ Empathy } & Experimental & 59 & 32.35 & 2.97 & 34.30 & 3.05 & +1.95 \\
\hline & Control & 61 & 32.22 & 3.30 & 32.90 & 3.06 & +.68 \\
\hline \multirow{2}{*}{$\begin{array}{l}\text { Conflict } \\
\text { Resolution Skills }\end{array}$} & Experimental & 59 & 80.08 & 15.31 & 89.03 & 14.03 & +8.95 \\
\hline & Control & 61 & 82.39 & 13.80 & 81.14 & 14.68 & -.125 \\
\hline
\end{tabular}

According to Table 4, communication skills pretest mean scores were calculated to be 95.30 in the experimental group and 92.67 in the control group. There was no significant difference between the experimental and control groups in terms of communication skills pretest mean scores $(t[118]=1.91, p=.236)$. Empathy pretest mean scores were calculated as 32.35 in the experimental group and 32.32 in the control group. There was no significant difference between the empathy pretest mean scores of the experimental and control groups $(t[118]=.220, \mathrm{p}=.826)$. Conflict resolution skills pretest mean scores were calculated as 80.08 in the experimental group and 82.39 in the control group. There was no significant difference between experimental and control groups in terms of their conflict resolution skills pretest mean scores $(t[118]=.868, \mathrm{p}=.387)$. The levels of the groups were equal before the implementation.

Looking at the data presented in Table 4, an increase was observed between the pre and posttests in the communication skills evaluation scale mean scores of the experimental group (Xpost97.64 - Xpre95.30 $=+2.3$ ); and a decrease was observed in the mean score of the control group (Xpost91.26 - Xpre92.67 =-1.4). An increase was observed between the pre and posttests in the empathy scale mean scores of the experimental group (Xpost34.30 - Xpre32.35 $=+1.95$ ), and a slight increase was observed in the mean score of the control group (Xpost32.90 - Xpre32.22 $=+0.65$ ). An increase was observed between the pre and posttests in the conflict resolution scale mean scores of the experimental group (Xpost89.03 - Xpre80.08 $=+8.3$ ), and a slight decrease was observed in the mean score of the control group (Xpost81.14 - Xpre82.39=-1.25).

Mean scores of the pre and posttests were examined in terms of their significance. For this purpose, ANCOVA analysis was carried out. In ANCOVA analysis, pretest scores are kept under control and posttest scores are compared. The criteria required to perform ANCOVA analysis were met in terms of normal distribution of data, homogeneous variance and equal slope of regression lines. The results of the ANCOVA analysis on comparing the posttest scores of the experimental and control groups are presented in Table 5. 


\begin{tabular}{lccccc}
\multicolumn{5}{l}{ Table 5: ANCOVA results regarding the posttest scores of the experimental and control groups } \\
\cline { 2 - 6 } Source & Sum of Squares & Df & Mean Square & F & Sig. \\
\hline Communication skills (pretest) & 3968.796 & 1 & 3968.796 & 27.901 & .000 \\
Group & 777.057 & 1 & 777.057 & 5.463 & $\mathbf{. 0 2 1}$ \\
Error & 16642.533 & 117 & 142.244 & & \\
Total & 1091196.000 & 120 & & & \\
& & & & & \\
Empathy (pretest) & 288.901 & 1 & 288.901 & 41.372 & .000 \\
Group & 53.877 & 1 & 53.877 & 7.715 & $\mathbf{. 0 0 6}$ \\
Error & 817.017 & 117 & 6.983 & & \\
Total & 136573.000 & 120 & & & \\
Conflict Resolution (pretest) & & & & & \\
Group & 8411.096 & 1 & 8411.096 & 61.666 & .000 \\
Error & 2535.811 & 1 & 2535.811 & 18.591 & $\mathbf{. 0 0 0}$ \\
Total & 15958.509 & 117 & 136.398 & & \\
\hline
\end{tabular}

According to Table 5, there was a significant relationship between the posttest mean scores of experimental and control groups for communication skill $[\mathrm{F}(1-117)=27.901$ $\mathrm{p}<.05]$, empathy skill $[\mathrm{F}(1-117)=41.372 \mathrm{p}<.05]$ and conflict resolution skill $[\mathrm{F}(1-117)=$ $61.666 \mathrm{p}<.05]$. According to the results obtained, "VRPP for Students Aged 11-18" increased the communication, empathy and conflict resolution skill levels of the experimental group.

\section{Discussion, Conclusion and Suggestions}

According to the results obtained from this research, it was observed that the "Violence Reduction Psychoeducation Program for Students Aged 11-18" was effective in increasing the communication skill levels of the students in the experimental group. A limited number of studies have been carried out on the effects of intervention programs on communication skill levels of the students and their results were similar to the results of this study. In the study conducted by Beşer and Çam (2009), the effectiveness of the positive interpersonal relationship development program on adolescents with tendencies towards crime was examined; and it was found that the program led to an increase in adolescents in the experimental group in terms of using positive relationship styles. According to the results of the experimental study by Şahin (2017) conducted with 32 students on the effect of the communication skills education program on their communication skill levels, the program was effective in increasing the communication skill levels of university students with weak communication skills. Looking at the results of the experimental study by Çetinkaya (2013) on students enrolled at 1st and 2nd grades of high school, it was concluded that the problem solving education group program implemented to the students contributed significantly to their problem-solving and interpersonal communication skills. According to the results of the experimental study by Damirchi and Bilge (2014) on the effects of peace education program on the communication skill levels of 7 th grade students, the program was found to be effective 
in increasing the communication and effective conflict resolution skill levels of 7th grade students. In their experimental study on the effects of anger management education on communication skills and coping skills with anger, Öz and Aysan (2011) concluded that anger management education program led to statistically significant increase in communication and anger management skill levels of adolescents.

According to the results obtained from this study, it was observed that the "Violence Reduction Psychoeducation Program for Students Aged 11-18" was effective in increasing the conflict resolution skill levels of the students in the experimental group. There have been studies on the effect of intervention programs on conflict resolution skill levels of students. According to the results of the study by Kutlu and Bedel (2019) regarding the effect of conflict resolution psychoeducation program on the conflict resolution skills of middle school students, it was found that the program increased conflict resolution skill levels of secondary school students. According to the results of the study conducted by Mutluoğlu and Serin (2012) regarding the effect of conflict resolution education program on conflict resolution skills of the 5th grade students, it was found that the program increased the conflict resolution skill levels of the students. In the research carried out by Taştan (2004), the conflict resolution and peer mediation education program that was implemented on 6th grade primary school students was reported to have positive effects on their conflict resolution skills and this effect continued according to the monitoring test which was administered three months later. According to the results of the study by Yildız and Eşkisu (2011), which aimed to test effect of problem-solving skill development program on problem solving skills of the 9th grade students, it was concluded that the program significantly increased the problem solving skill levels of the students. In the study conducted by Latipun, Nasir, Zainah and Khairudin (2012), statistically significant differences were found between conflict resolution skill levels of adolescents were implemented the peace education program and who were not. According to the results of the experimental study by Uysal and Temel (2007) conducted with 78 primary school students regarding the effect of the anti-violence education program on their conflict resolution skills, it was found that the program increased the conflict resolution skill levels of the students at a statistically significant level. Many other studies also concluded that early intervention programs such as conflict resolution training reduced negative behaviors such as violence and aggression in students (Akgün and Araz, 2010; Arslan, Hamarta, Arslan and Saygin 2010; Bemak and Keys, 2000; Kaşık and Kumçak 2014) and they were effective in using conflict resolution skills for resolving the conflict experienced (Ateş, 2014; Kaya, 2013). In another study, it was found that there was a positive meaningful relationship between conflict resolution and communication skills of students; and their conflict resolution skill levels increased with the increase of their communication skill levels (Küçük, 2012).

According to the results obtained from this study, it was observed that the "Violence Reduction Psychoeducation Program for Students Aged 11-18" was effective in increasing the empathy skill levels of the students in the experimental group. There have been studies on the effect of intervention programs on empathy skill levels of students. 
In the study conducted by Gemci (2015), it was found that the emphatic skill education program increased the emphatic skill levels of 8 th grade students. According to the results of the experimental study conducted by Akgül and Yavuzer (2017) regarding the effect of interpersonal sensitivity education on the empathy skills of the students, the program significantly increased the empathy skill levels of the students. In the study conducted by Sağkal, Türnüklü and Totan (2012), the effect of the peace education program on the empathy levels of primary school students was examined; and it was concluded that the peace education study conducted with the students in the experimental group increased their empathy levels. In studies examining the effect of peer mediation education on the empathy skills of students, it was found that this education was effective in improving empathy skills of the students (Koruklu, 2003; Schaeffer and Rollin, 2001). To sum up, according to results of the previous studies, early intervention programs were observed to develop skills of recognizing emotions and expressing emotions appropriately in students, which were the sub dimensions of the empathy skills (Akgün and Araz, 2010; Schrumpf, Crawford and Bodine, 2007).

Previous studies reported that there the relationship of violence and aggression with communication, conflict resolution and empathy skills was negative, and that violence and aggression levels of students decreased with the increase in the levels of communication (Hasta and Güler, 2013; Kurtyllmaz, 2005), conflict resolution (Akgün, Araz and Karadağ, 2007; Tapan, 2006) and empathy skills (Hasta and Güven, 2013; Filiz, 2009; Siyez and Kaya, 2011).

According to the studies that were carried out in the light of the research mentioned above, there is a requirement for the integration of the programs, which would reduce the violent and aggressive behaviors of students and increase their communication, conflict resolution and empathy skill levels, into the education system. Hence, today, education is expected to develop individual and social aspects of students and to provide them with basic life skills for a healthy, happy and peaceful life harmonious with the society they live in rather than providing them with academic information and equipping hem with information based on memorization. In schools where the other developmental aspects of the students are neglected, many negative cases are experienced such as violence, aggression, crime, peer bullying, which destroy both the school climate and their community. In order to avoid these negative situations, first of all, basic life skills that the students would require should be taught in schools. These life skills cannot be expected to develop spontaneously in students without specific education. Without receiving this education, students would not know the constructive and functional conflict resolution methods, effective communication skills and the use of appropriate empathic language. Due to this lack of knowledge, there are many students who try to solve their problems by shouting and protect their rights through violence as well as teasing, beating, oppressing, humiliating or alienating each other. Unless students are taught basic life skills, they would continue to use these methods, which they believe to be appropriate. Students need to attain knowledge and skills on coping with the difficulties they face, developing communication, conflict resolution, empathy skills and 
self-confidence, managing anger and coping with anxiety. Students could attain these knowledge and skills only when they are taught within certain programs.

First of all, it is necessary to develop educational programs that are appropriate to the readiness levels of students in different age groups, are based on research, include basic life skills such as communication, conflict resolution and empathy, and teach how to cope with conflicts, problems and difficulties. Then qualified professionals should be trained to implement these programs to students at schools. The implementation of these programs falls within the scope of psychological counseling and guidance services, and the professional staff to implement these programs to students are the psychological counselors in schools. Psychological counselors should be trained to qualify in teaching basic life skills to students; and, programs that would provide students with basic life skills should be placed at the center of guidance and psychological counseling services in schools. This program has been developed for and offered to the psychological counselors at schools to teach students basic life skills within the scope of improving and protective psychological counseling and guidance services.

As a result, "VRPP for Students Aged 11-18" increases communication, conflict resolution and empathy skill levels of students. According to the results of the study, the following suggestions were made: Education programs, which would provide students with basic life skills and improve them in terms of communication, conflict resolution and empathy, should be developed. These education programs should be implemented systematically and deliberately within the scope of the psychological counseling and guidance services as a part of the curriculum in certain hours similar to the other courses. In-service training could be provided on the subjects such as communication, conflict resolution and empathy, primarily to the psychological counselors and then to the classroom teachers, who teach basic life skills to students in schools. Informative seminars should be given to parents as parts of the lives of students on such topics as communication, conflict resolution and empathy, and they should be administered educational programs to attain skills within the scope of the psychological counseling and guidance services. This study is limited to the implementation, which was made in a certain region and on a certain age group. Long term and comprehensive experimental studies could be carried out in different regions and on different age groups. In Turkey, there is a requirement for further studies on developing programs regarding such topics as communication, conflict resolution and empathy, and analyzing the effects of these programs on students. It is believed that the results of this study would have significant contributions to the field of protective, developing and preventive guidance and psychological counseling. 


\section{References}

Akan, Y. (2018). "Şiddeti Azaltma Psikoeğitim Programı"nın (ŞAPP) eşine şiddet uygulayan erkeklerin saldırganlık, duygu yönetimi ve ilişki özyeterlik düzeylerine etkisinin incelenmesi (Doktora tezi). Mersin Üniversitesi, Eğitim Bilimleri Enstitüsü, Mersin.

Akgül, N., \& Yavuzer, N. (2017). Kişilerarası duyarlılık eğitiminin üniversite öğrencilerinin empati ve iletişim becerilerine etkisi. Sosyal Bilimler Araştırmaları Dergisi, 14(2), 539-554.

Akgün, S., Araz, A. ve Karadağ, S. (2007). Anlaşmazlıklarımızı çözebiliriz: İlköğretim öğrencilerine yönelik bir çatışma çözümü eğitimi ve psiko-sosyal etkileri. Türk Psikoloji Dergisi, 22(59), 43-67.

Akgün, S. ve Araz, A. (2010). Anlaşmazlıkları çözebiliriz çatışma çözümü eŏitim programi. Ankara: Nobel Yayın Dağıtım.

Arslan, C., Hamarta, E., Arslan, E. ve Saygin, Y. (2010). Ergenlerde saldirganlık ve kişilerarası problem çözmenin incelenmesi. İlköğretim Online, 9(1), 379-388.

Ateş, N. (2014). Çatışma çözme eğitiminin 6. sınıf öğrencilerinin çatışma çözme becerileri ve özsaygı düzeylerine etkisi (Yayınlanmamış doktora tezi). Haliç Üniversitesi, Sosyal Bilimler Enstitüsü, İstanbul.

Bacıŏlu, S. D. (2014). Şiddet ve saldırganlığın azaltılmasında önleme ve müdahale programlarının etkililiği: Meta analiz çalışması. Türk Psikolojik Danışma ve Rehberlik Dergisi, 5(42).

Balc1, F. (2017). Okulda arabuluculuk. Ankara: Nobel Akademik Yayıncılık.

Balta, E. E. (2011). Waldmann modeli ile yapılan metin öğretiminin 8. sinıf öğrencilerinin okuduğunu anlama, eleştirel düşünme ve yaratıcı düşünme becerilerine etkisinin incelenmesi (Yayınlanmamış doktora tezi). Fırat Üniversitesi, Eğitim Bilimleri Enstitüsü, Elazı̆̆.

Bemak, F. and Keys, S. (2000). Violent and aggressive youth: Intervention and prevention strategies for changing times. Practical skills for counselors. Corwin Press, Inc., 2455 Teller Rd., Thousand Oaks, CA 91320-2218.

Beşer, N. G. ve Çam, O. (2009). Suça yatkın ergenlerde olumlu kişilerarası ilişkiler geliştirme programının etkinliğinin incelenmesi. Anadolu Psikiyatri Dergisi, 10(3), 226.

Bryant, B. (1982). An index of empathy for children and adolescents. Child Development, 53, 413- 425.

Çetinkaya, Ş. (2013). Lise öğrencisi erkek ergenlerde problem çözme ĕ̆itiminin; problem çözme becerisi, kişilerarası ilişki tarzı ve öfke kontrolü üzerine etkisi (Yayınlanmamış yüksek lisans tezi). Adnan Menderes Üniversitesi, Sağlık Bilimleri Enstitüsü, Aydın.

Çokdolu, N. (2013). Karakter eğitimi programının ilköğretim 2. kademe öğrencilerinin çatışma çözme ve saldırganlık düzeylerine etkisi (Yayımlanmamış yüksek lisans tezi). Necmettin Erbakan Üniversitesi, Eğitim Bilimleri Enstitüsü, Konya.

Dökmen, Ü. (2008). İletişim çatışmaları ve empati. İstanbul: Remzi Kitapevi. 
Damirchi, E. S. ve Bilge, F. (2014). Barış eğitimi programının yedinci sınıf öğrencilerinin çatışma çözme ve iletişim becerilerine etkisi. Ĕ̆itim ve Bilim, 39(175).

Eşkisu, M. ve Yıldız, S. A. (2011). Problem çözme becerisini geliştirme programının 9. Sınıf öğrencilerinin problem çözme becerisi üzerindeki etkisi (Yayımlanmamış yüksek lisans tezi). İstanbul Üniversitesi, Sosyal Bilimleri Enstitüsü, İstanbul.

Elbogen, E. B. and Johnson, S. C. (2009). The intricate link between violence and mental disorder: Results from the national epidemiologic survey on alcohol and related conditions. Arch Gen Psychiatry, 66(2), 152-161

Erdemir, N. ve Kış, A. (2017). Okul yöneticilerinin okul rehberlik ve psikolojik danışma hizmetleri ile ilgili görüşleri. İnönü Üniversitesi Ĕ̆itim Bilimleri Enstitüsü Dergisi, 4(8), 34-47.

Farrington, D. P. (1991). Childhood aggression and adult violence: Early precursors and later life outcomes. The development and treatment of childhood aggression, 5, 29.

Filiz, A. (2009). Farklı lise türlerindeki öğrencilerin empatik eğilimleri ve saldırganlık düzeylerinin incelenmesi (Kartal ilçesi örneği) (Yayımlanmamış yüksek lisans tezi). Yeditepe Üniversitesi, Sosyal Bilimler Enstitüsü, İstanbul.

Gemci, H. (2015). İlköğretim 8. sinıf öğrencilerine uygulanan etkili iletişim ve empatik beceri eğitiminin öğrencilerin iletişim ve empatik becerilerine etkisinin incelenmesi (Yüksek Lisans Tezi). Dokuz Eylül Üniversitesi, Eğitim Bilimleri Enstitüsü, İzmir.

Gündoğdu, R. (2009). Yaratıcı drama temelli çatışma çözme programının ergenlerde öfke, saldırganlık ve çatışma çözme becerisine etkisi (Doktora tezi). Selçuk Üniversitesi, Sosyal Bilimler Enstitüsü, Konya.

Hasta, D. ve Güler, M. E. (2013). Saldırganlık: kişilerarası ilişki tarzları ve empati açısından bir inceleme. Ankara Üniversitesi Sosyal Bilimler Enstitüsü Dergisi, 4 (1), 64-104.

İrfaner, S. (2009). Öğrenciler arasında gerçekleşen zorbalık eylemleri ve zorbalık konusunda öğrencilerin, öğretmenlerin ve okul yöneticilerinin tutum ve görüşleri (Yayımlanmamış doktora tezi). Hacettepe Üniversitesi Sosyal Bilimler Enstitüsü, Ankara.

Kabasakal, Z. (2013). The effects of mother education programs on the functionality, anger management and conflict solution levels of families. Eurasian Journal of Educational Research, 52, 1-20.

Kabasakal, Z. T., Sağkal, A. S. ve Türnüklü, A. (2016). Barış eğitimi programının öğrencilerin şiddet eğilimleri ve sosyal sorun çözme becerileri üzerindeki etkileri. Eğitim ve Bilim, 40(182).

Kaşık, N. C. ve Kumcağı, H. (2014). The effects of the conflict resolution and peer mediation training program on self-esteem and conflict resolution skills. International Journal of Academic Research, 6(1).

Kaya, B. (2013). Barış eğitimi programının kültürlerarası yeterlilik ve çatışma çözme stratejilerine etkisi (Yayınlanmamış yüksek lisans tezi). Kocaeli Üniversitesi Sosyal Bilimler Enstitüsü, Kocaeli.

Kılıçarslan, E. (2011). İletişim kurma becerileri. İstanbul: Kriter Yayınları. 
Koç, B. (2014). Kişilerarası ilişki tarzlarının saldırganlık ile ilişkisi. Uluslararası Türkçe Edebiyat Kültür Ĕ̆itim Dergisi, 3(4), 160-182.

Koç, B., Terzi, Y. ve Gül, A. (2015). Üniversite öğrencilerinin iletişim becerileri ile kişilerarası problem çözme becerileri arasındaki ilişki. Uluslararası Türkçe Edebiyat Kültür Ĕ̆itim Dergisi, 4(1), 369-390.

Korkut, F. (2004). Okul temelli önleyici rehberlik hizmetleri. Ankara: Anı Yayıncılık.

Korkut, F. (1996). İletişim becerilerini değerlendirme ölçeğinin geliştirilmesi: Güvenirlik ve geçerlik çalışmaları. Psikolojik Danışma ve Rehberlik Dergisi, 2 (7), s. 18-23.

Koruklu, Ö. N. (1998). Arabuluculuk eğitiminin ilköğretim düzeyindeki bir grup öğrencinin çatışma çözme davranışlarına etkisinin incelenmesi (Yüksek lisans tezi). Ankara Üniversitesi, Sosyal Bilimler Enstitüsü, Ankara.

Koruklu, Ö. N. (2003). Arabuluculuk eğitiminin iletişim ve çatışma çözme becerisine etkisi. Bir grup üniversite öğrencisi üzerinde çalı̧̧ma (Yayınlanmamış doktora tezi). Ege Üniversitesi, Eğitim Bilimleri Enstitüsü, İzmir.

Kurtyılmaz, Y. (2005). Öğretmen adaylarının saldırganlık düzeyleri ile akademik başarıları, iletişim ve problem çözme becerileri arasındaki ilişkiler: (Anadolu Üniversitesi ve Osmangazi Üniversitesi öğrencileri üzerinde bir araştırma) (Yüksek lisans tezi). Anadolu Üniversitesi, Eğitim Bilimleri Enstitüsü, Eskişehir.

Kutlu, A. ve Bedel, A. (2019). Çatışma çözme programının ortaokul öğrencilerinin çatışma çözüm becerilerine, sürekli öfke ve öfke ifade tarzlarına etkisi. Ilköğretim Online, 18(1).

Küçük, D. P. (2012). Müzik öğretmenliği anabilim dalı öğrencilerinin iletişim ve problem çözme becerileri. Gazi Üniversitesi Gazi Eğitim Fakültesi Dergisi, 32(1), 33-54.

Latipun, S., Nasir, R., Zainah, A. Z. and Khairudin, R. (2012). Effectiveness of peer conflict resolution focused counseling in promoting peaceful behavior among adolescents. Asian Social Science, 8(9), 8.

McCart, M. R., Prienter, P. E., Davies, N. H. and Azen, R. (2006). Differential effectiveness of behavioral parent- training and cognitive behavioral therapy for antisocial youth: A meta-analysis. Journal of Abnormal Child Psychology, 34(4), 525-541.

Mutluoğlu, S. ve Serin, O. (2012). Çatışma çözme eğitim programının ilkokul 5. sınıf öğrencilerinin çatışma çözme becerilerine etkisi. Turkish International Journal of Special Education and Guidance \& Counselling (TIJSEG), 1(1), 25-34.

Ögel, K., Tarı, I. ve Eke, C. Y. (2006). Okullarda suç ve şiddeti önleme. İstanbul: Yeniden Yayınları,

Öner, U. (1999). Çatışma çözme ve arabuluculuk eğitimi. Ankara: Nobel Yayın Dağıtım.

Öz, F. S. and Aysan, F. (2011). The effect of anger management training on anger coping and communication skills of adolescents. International Online Journal of Educational Sciences, 3(1).

Özcebe, H., Ulukol, B., Mollahaliloğlu, S., Yardım, N. ve Karaman, F. (2008). Sağlık hizmetlerinde okul să̆ lı̆̆ kitabı. Ankara: Sağlık Bakanlığı.

Sağkal, A. S. (2011). Barış eğitimi programının ilköğretim 6. sınıf öğrencilerinin saldırganlık eğilimleri, empati düzeyleri ve barışa ilişkin görüşleri üzerindeki etkisinin 
incelenmesi (Doktora tezi). Dokuz Eylül Üniversitesi, Eğitim Bilimleri Enstitüsü, İzmir.

Sağkal, A. S., Türnüklü, A. ve Totan, T. (2012). Kişilerarası barış için empati: Barış eğitiminin empati becerilerine etkileri. Kuram ve Uygulamada Ĕ̆itim Bilimleri, 12(2), 1447-1460.

Schaeffer, S. and Rollin, A. S. (2001). The evaluation of a community based conflict resolution program for African American children and adolescent. Research for Educational Journal, 6(1), 33-50.

Schreiter, S., Pijnenborg, G. H. and Rot A. H. M. (2013). Empathy in adults with clinical or subclinical depressive symptoms. Journal of Affective Disord. 150, 1-16.

Schrumpf, F., Crawford, D. K. and Bodine, R. J. (2007). Okulda çatışma çözme ve akran arabuluculuk (Çev: F. Gül. Akbalık ve B. Dilek Karaduman). Ankara: İmge Kitabevi.

Siyez, D. M. ve Kaya, A. (2011). Akran zorbalığg gruplarında empatik eğilim. İnönü Üniversitesi Ĕ̆itim Fakültesi Dergisi, 12 (2), 23-43.

Stevahn, L., Johnson, D. W., Johnson, R. T. and Real, D. (1996). The impact of a cooperative or individualistic context on the effectiveness of conflict resolution training. American Educational Research Journal, 33(4), 801-823.

Şahin, F. Y. (2017). Grupla iletişim becerileri eğitiminin üniversite öğrencilerinin iletişim beceri düzeylerine etkisi. Ankara: Pegem Akademi.

Tagay, Ö., Baydan, Y. ve Acar, N. V. (2010). Sosyal beceri programının (blocks) ilköğretim ikinci kademe öğrencilerinin sosyal beceri düzeyleri üzerindeki etkisi. Mehmet Akif Ersoy Üniversitesi Sosyal Bilimler Enstitüsü Dergisi, (3), 19-28.

Tapan, Ç. (2006). Barış eğitimi programının öğrencilerin çatışma çözme becerileri üzerineki etkilerinin incelenmesi (Doktora tezi). Dokuz Eylül Üniversitesi, Eğitim Bilimleri Enstitüsü, İzmir.

Taştan, N. (2004). Çatışma çözme ve akran arabuluculŭ̆u ĕ̆itimi programlarının ilköğretim altınc sınıf öğrencilerinin çatışma çözme ve akran arabuluculuğu becerilerine etkisi (Yayınlanmamış doktora tezi). Ankara Üniversitesi, Eğitim Bilimleri Enstitüsü, Ankara. 
Author(s) will retain the copyright of their published articles agreeing that a Creative Commons Attribution 4.0 International License (CC BY 4.0) terms will be applied to their work. Under the terms of this license, no permission is required from the author(s) or publisher for members of the community to copy, distribute, transmit or adapt the article content, providing a proper, prominent and unambiguous attribution to the authors in a manner that makes clear that the materials are being reused under permission of a Creative Commons License. Views, opinions and conclusions expressed in this research article are views, opinions and conclusions of the author(s). Open Access Publishing Group and European Journal of Education Studies shall not be responsible or answerable for any loss, damage or liability caused in relation to/arising out of conflicts of interest, copyright violations and inappropriate or inaccurate use of any kind content related or integrated into the research work. All the published works are meeting the Open Access Publishing requirements and can be freely accessed, shared, modified, distributed and used in educational, commercial and non-commercial purposes under a Creative Commons Attribution 4.0 International License (CC BY 4.0). 